\title{
AOR
}

Selected Papers of \#AolR2021:

The 22nd Annual Conference of the Association of Internet Researchers Virtual Event / 13-16 Oct 2021

\section{ANALYZING THE PLATFORM ECONOMY - FEUDALISM, MEDIEVALISM AND COLONIALISM AS USEFUL FRAMEWORKS}

\author{
Benedetta Brevini \\ University of Sydney \\ Jakob Linaa Jensen \\ Aarhus University \\ Mirca Madianou \\ Goldsmiths, University of London \\ Nick Couldry \\ London School of Economics \\ Ulises Mejias \\ State University of New York, Oswego

\section{Panel introduction}

The platform economy challenges existing economic systems, social interactions and participation as well as the very foundation of democracy. As data is replacing labor as the central economic good, economy, society, class structures and democracy might change fundamentally. Or we might experience old wine in new bottles. Karl Marx famously said that history tends to repeat itself, first as comedy, later as tragedy. In this panel we ask, whether history is repeating itself?

The logics of Internet platforms are often monopolizing and repressive. In the platform economy we have sacrificed our privacy for convenience. This is at odds with optimist expectations of the Internet as equalizing, democratizing and in general leading to more freedom and prosperity. The free, unregulated Internet, the dream of Internet evangelists like John Perry Barlow and Esther Dyson, have been up for grabs. It has been colonized, marketed and dominated by players like the big five, Apple, Microsoft, Facebook, Google and Amazon.

Suggested Citation (APA): Brevini, B., Jensen, J., Madianou, M., Couldry, N., and Mejias, U. (2021, October). Analyzing the Platform Economy - Feudalism, Medievalism and Colonialism as Useful Frameworks. Panel presented at AolR 2021: The 22nd Annual Conference of the Association of Internet Researchers. Virtual Event: AolR. Retrieved from http://spir.aoir.org. 
Such contradictions necessitate a historical focus in order to understand both how these logics came into being and how negative consequences of the platform economy night be overcome. By using historical prisms we might be more informed on our present and our future. In this panel we present and discuss contrasting historical perspectives on the platform economy. By using certain historical frameworks as prisms to focus on and analyze contemporary trajectories we might be able to identify, distill and scrutinize well known mechanisms of power, exploitation and dominance.

The panel's speakers employ different historical perspectives but focus mainly in two periods: medieval times and the age of colonialism. Both periods were characterized by a strong correlation between a certain economic system and the exercise of political power. Structured inequalities in systems of labor, trade and distribution of wealth had significant consequences for the distribution and (re)production of political power. Medieval and colonial societies were each based on logics of exploitation and dominance, ideologically legitimized by references to first God, later the nation, what Marx would have referred to as the superstructures of economic logics. In these systems, individual agency and possibilities were limited compared to today. In medieval society it was hard to change the estate in which you were born, in colonial times it was hard to change your role in the international system. And the fixed structures were basically grounded in economic logics.

This is not a rigid Marxist or historical-materialistic panel but we are focusing on relations between economic logics and political power by discussing perspectives of surveillance, control and punishment in medieval societies, logics of feudalism then and now.

Benedetta Brevini takes the point of departure in the Middle Ages and demonstrates how technology platforms operate on principles similar to the feudalist structures of medieval society. Brevini discusses the concept of "the digital lord" and by a case study of tech giant Amazon she explains how the lord, defined as a platform that uses a dominant position to suppress competition, by controlling by design which particular products users see and by favouring their own brands over third party suppliers. The "lord" is (to quote Marx) the master of the process of production and of the entire process of social life. Contrary to Medieval society the lord's power is not based on manual work by serfs or slaves but by data extraction and exploitation.

Jakob Linaa Jensen takes the medieval perspective a bit further. Besides agreeing with Brevini that we definitely witness a new digital feudalism he/she also focuses on mutual surveillance, what he/she with a reference to Michel Foucault calls an "omnopticon". By using the Medieval village as a metaphor for social life he demonstrates how platform power is not only exercised by greedy tech giants but by citizens themselves, by participating and sub-ordinating to platform logics of participation and recognition, not at least in "the friending systems" and the "like economy. Further, social life in the platform economy is often based on mutual surveillance and strong logics of social control. He/She discusses "virtual pillories" and "digital witch hunts" as mechanisms by which the masses control each other, narrowing free speech and individual agency. This has also significant political and democratic consequences as alternative voices might be increasingly 
suppressed. In short, the return to the (digital) medieval village represents a backlash for freedom, agency and democracy.

In the next paper, we move historically to the age of colonialism, an era characterized by exploitation and unequal power relations legitimized in a certain world order. Mirca Madianou emphasizes how colonialism still is at play, now reworked by practices of innovation and digitization. Madianou discusses the notion of technocolonialism, understood as the ways by which digital innovation and data practices revitalise colonial legacies in the humanitarian and international development sectors. Technocolonialism refers to the convergence of digital developments with the structures of the platform economy and market forces and the extent to which they reinvigorate and materialise colonial relationships of dependency. Madianou particularly focuses on the aid sector as an example of these tendencies. The paper first outlines why colonialism is an appropriate framework, then illustrates how digital innovation and data practices rework colonial legacies within the aid sector before finally arguing for the wider relevance of this framework which extends beyond the actual case study.

Nick Couldry and Ulises Mejias go further and, drawing on their recent book, The Costs of Connection (2019) argue that the specificity of contemporary forms of data extraction is best understood by seeing it as a genuinely new stage of colonialism which is based around the appropriation not (as in historic colonialism) of land, its resources and the bodies to work those resources, but the flow of human life itself, made valuable in the form of data. This thesis of 'data colonialism' is offered as a characterization not just of what is happening with data in historic colonies, but right across the world, including the Global North. At the same time, deep continuities between historic colonialism's rationalization of resource appropriation through supposedly superior 'rationality' and today's logics of dataism and Big Data become visible once we see both, following the Peruvian sociologist Anibal Quijano, as forms of coloniality.

The panel is based on several recent books written by the panel participants. By bringing together our ideas and perspectives we hope to generate a stimulating discussion and contribute to a unified research agenda of historically focused analyses of the platform economy and beyond.

\section{Paper 1}

FROM TECH GIANTS TO DIGITAL LORDS: THE PROMISE (OR TRAGEDY) OF THE DIGITAL FEUDALISM FRAMEWORK

\section{Benedetta Brevini, University of Sydney}

Many scholars in the last two decades have investigated the unprecedented consolidation of communication systems, exploring the increasing globalisation of capitalist relations and rationales; the concerted pursuit of neo liberal economic policies, and the roll-out of digital technologies, particularly the emergence of the internet as a mass utility (Brevini and Murdock, 2017). The focus on data accumulation has been put at centre stage in several recent works, including Fuch's Big data capitalism (2019) Zuboff's Surveillance Capitalism (2019) and Srnicek's Platform Capitalism (2017). The common themes of 
these latest works are that data has a crucial value, data collection is highly unequal and tends to replicate the same power asymmetries in societies.

While these frameworks are useful in understanding the developments of global Tech Giants, in recent work (Brevini, 2021) I have argued that if we want to really capture the political, economic and ideological power of Tech Giants and make sense of the extreme inequality, uncontrolled market dominance, precarity, and the progressive privatisation of communication policy we are witnessing, then a new analytical framework is needed. More precisely, as I have explored in "Amazon: understanding a communication giant" (Brevini,2021) it is crucial to understand these Communication Giants beyond their characterization as successful capitalists, and to embrace the more promising framework of Tech Giants as Digital Lords in the context of Digital Feudalism.

\section{Digital Lords and Digital Feudalism}

What we understand as feudalism is a significant structure of the Middle Ages. Although with many versions across European societies of the time, this framework is useful to understand a series of relationships between a landowner (the lord) and their vassals and serfs with their duties, obligations and various degrees of curtailed freedoms. As the lords of the middle ages extracted rents, imposed loyalties, and profited from resources that were scarce, today's Digital Lords exert their powerful dominance on their contractors, users and citizens: us. In Marx's words a Lord is "the master of the process of production and of the entire process of social life" (Marx, 2018).

What are the characteristics of Digital Lord, how do they wield their power? A Digital Lord is a platform that uses a dominant position to suppress competition, by controlling by design which particular products users see and by favoring their own brands over third party suppliers. Each platform builds a Digital Estate that is based on membership (in Amazon's case, the products as services) and aims to lock users in. Each platform extracts rents (Mazzuccato, 2018) from its third-party suppliers (vassals) that pay a fee to receive the other services of the Lord following the logic of feudal beneficia ( for example, Amazon Fulfilments, Amazon Advertisement, and Amazon Clouds). Thus, the sellers that do not advertise on the platform find themselves at a severe disadvantage in the market that the Digital lord rules; like medieval vassals in an estate, loyal sellers/vassals need the Lord's protection to survive. The Digital Lord is also a platform that gives users the illusion of options, but because of clear design choices and business strategies, de facto imposes on users their already-made decisions. The Digital Lord is also a platform that collects data about serfs and peasants in the Realm (the users) through various ubiquitous technologies. Finally, The Digital Lord is a company that exploits its financial strength, strong research capability and market dominance to set a political agenda in the context of Digital Feudalism.

In order to test the framework, I will focus on the case of Amazon. Firstly, Amazon has been able to exploit network effects of communication systems (Liebowitz, Stan J., and Stephen E. Margolis, 1994) on several levels to become a Digital Lord. When Amazon started, it used its broad networks to bring in diverse suppliers, predominantly to the benefit of its customers. The more members it attracted, the more interesting it became for additional customers and the more difficult it became for alternative providers to compete. But more indirect network effects have impacted on Amazon's extraordinary 
success: the more consumers use Amazon, the more the platform becomes attractive not just for customers, but for other indirect players in the market, third party businesses. The more third-party retailers it attracts, the more Amazon can dictate the conditions under which they can use the platform to sell. Such conditions or fees are "rents" that progressively weaken the ecosystem of third-party sellers, establishing a more repressive Digital Estate that gives retailers no other choice but to accept the condition of the Lord. Moreover, Amazon does not only compete with major e-shopping companies offering platforms for retailers: it also competes with the same sellers as a producer, that sells its products in the same ecosystem.

As one of the Digital Lords with dominant market power, Amazon uses its assertive position to restrain competition, by controlling which products users see in their Realm and by promoting their own brands. Meanwhile, Amazon's advertising business is also thriving, so retailers are also forced to pay additional rent to advertise on the platform. This uncontested dominance allows a digital lord like Amazon to push a mechanism of loyalty to the company (for both vassals and serfs) to keep all users, providers and retailers permanently attached to their services. This is through the creation of a proprietary system environment, enriched by the incredible technological assets of the company (AWS for example) offers customized and integrated hardware products, services that are designed to keep vassals and serfs within the same estate forever.

Another factor is crucial in pushing the concentration dynamics and the consolidation of market power of Amazon: its impressive financial resources in the form of stock market capital that enables continuous acquisition and the elimination of potential competitors. The digital lord's substantial capital enables continuous expansion into new territories; lord and estate have continued to sweep across new lands and conquer other, smaller lords and estates, bringing their serfs (workers) and vassals (third parties) under its aegis. The lord's growing capital also enables expansion through experimentation; serfs are encouraged to develop new goods that the estate will be able to sell to new subjects.

The modern expansionist digital estate requires different mechanisms to grow in comparison with the estates of old, and Amazon has certainly made use of these mechanisms to increase its political influence. It has engaged in increasingly sophisticated lobbying activities. The court of the lord has expanded in recent years to include a number of expert lobbyists, drawn from the ranks of the political-corporate elite, who have been undertaking activities to try to persuade lawmakers (and other parties) of the worthiness of the corporation's actions

\section{Data extraction as core business}

Amazon's business strategies, like the business strategies of other Digital Lords, have always been characterized by an obsession for data extraction and profile building. Thus, Amazon as a Digital Lord has systematically collected, matched and evaluated users' behavior on their platform and beyond to create an impressive database of profiles. These large volumes of data are used to create ever-more differentiated user profiles, which are employed to anticipate what users want. But this data is also fundamental to feed a number of other businesses of the Digital Lord; they are used to develop the most successful products sold under the Amazon brands, crucially tied to consumers' preferences (to reiterate their status of vassals, third party sellers on Amazon don't have 
access to their own customers 'data). These profiles serve as an important input for their research and development and they feed all Artificial Intelligence expansions and Internet Things products. Ultimately, they also contribute to their growing advertising activities, aimed at influencing users' behavior and actions. 


\section{Paper 2 \\ THE MEDIEVAL INTERNET - DIGITAL FEUDALISM, OMNOPTICAL SURVEILLANCE AND SOCIAL CONTROL IN THE PLATFORM ECONOMY}

\section{Jakob Linaa Jensen, Aarhus University}

In this paper, I argue that medievalism might form a coherent perspective for understanding logics of participation, power and dominance in the platform economy. I will argue, that the medieval perspective, understanding contemporary digital, social media-savvy society through metaphors and concepts from medieval society, is a useful prism for investigating the social and political challenges facing us twenty years into the twenty-first century. The main argument is that apparently distinct social phenomena related to the spread of new media are related and a product of logics that dominated medieval society, not at least those of control, surveillance and feudalism.

I particularly use the medieval village as a metaphor for the social experience of the platform economy. I discuss how mutual surveillance, social control and censorship are also parts of the new platform economy order. It is a paradox that the Internet, the ultimate symbol of modernity, transparency and enlightenment facilitates logics of enclosure, censorship and social control. Much of this is linked to the enormous increase of visibility. In the medieval village, contrary to modern society, it was hard not to be seen and observed.

I will argue that the socially mediated public sphere combines two phenomena, visibility and mutual surveillance. We are currently witnessing an "omnopticon", where everybody watches everybody via a complicated network of mutual, mediated surveillance techniques, mass media phenomena and 24/7 activities on the Internet.

Social interactions in the age of social media is shockingly similar to medieval village logics of mutual surveillance. Even if not actively commenting or liking, users keep an eye on each other, through what I have elsewhere dubbed as a social sixth sense. Many people write and publish on social media based on anticipated reactions. Social media, like the rest of the Internet, was intended to set people free, but as it gathered momentum the consciousness of the omnopticon intruded on the surface of all Internet activities, creating a norm that cripples rather than liberates, making people conform even more to existing norms of what is perceived as mass approved behaviour.

This is particularly striking in the case of what I call "Digital pillories". In medieval society, the pillory was one of the great instruments of public shaming. Here offenders were exhibited for shorter or longer times for the purpose of public shaming. They received public ridicule, outright hatred and physical acts like hitting and spitting from the bypassers. The pillory was a strong instrument of social control. In a close-knit society where everybody knew each other, the price of rejection and exclusion from society was high. Some people believe that the pillory is a thing of the past in enlightened societies, under the rule of law, where punishment is concealed from the public institutionally with prisons. The truth is that although the physical pillories were removed from city squares during the Age of Enlightenment, public shaming has never ceased to have a powerful presence in modern society, from newspaper stories and the televised spectacle of 
celebrity trials - or cases that create celebrities - to the Internet's amplification and massification of public shaming.

First, contrary to the mass media age where editorial filters had to be passed, everybody can now publish and, as importantly, film, allowing for posting all kinds of accusations, whether right or wrong. Secondly, information posted online floats around permanently, even if a post might be removed or a site might go bankrupt. One of the affordances of the Internet is the ability to copy and distribute, which has exponentially increased. Online rumours have proven hard to extinguish, Finally, we are living in the age of sharing. Rumours, reputations spread like a wildfire. The more controversial or sensational, the faster it spreads. From the outset of digital social media, these tools have found targets in criminals (convicted or not), politicians, restaurants, companies and ordinary citizens who for some reason have fallen into disregard.

Not all digital pillories are created explicitly with the purpose of public shaming. The last decades we have seen an explosion of online rating services, evaluating everything from travel agencies and restaurants to teachers and solicitors. The idea is in line with the touted notion that the middlemen - the tourist guide, the critic, the professional - were now unnecessary. Rather than relying on curated advice by experts, everybody can become a reviewer. The idea of trusting fellow consumers and citizens is immediately appealing. They are in the same boat and one might even filter the reviews to read from someone like oneself, for instance singles, citizens of New York or mothers with kids. Further, in rating portals the expertise is crowdsourced, Wikipedia-style, while the number of reviews increase the reliability, making one odd review less important. But here, too, there is a large opening for rumour and slander.

Another example of mechanisms of control in the "digital" medieval village is digital witch hunts. Witch trials and witch hunts are often seen as characteristic of medieval society, although in fact they only started in the High Middle Ages, and achieved critical mass only later, in the sixteenth and seventeenth century. Online witch hunts only deviate from their historic predecessors in the method of punishment. After all, the mob does not have formal judicial power. But the rapid and often wrong judgement of "the social media court of justice" can do real harm to their victims anyway. There are numerous examples of teenagers who have committed suicides because of online bullying. And innocent people have been driven to suicide or into hiding to escape Internet spread accusations of crimes or other misdeeds that they have not, in fact, committed. Even if the claims do turn out to be true, the "trial" of these people in Social Networks has a way of vitiating the fundamental right of the accused in a democratic society to a fair and unbiased trial by an independent court. The judgement by the crowd belongs in archaic contexts like the medieval marketplace. In the paper presentation I use the "witch hunt" on Reddit in the aftermath of the Boston Marathon bombing as an illustrative example.

In short, by using the Middle Ages and particularly the Medieval village as an analytical prism, I identify logics of mutual surveillance social control and thereby the exercise of power on a micro level, facilitated by the affordances of the platform economy. 


\section{Paper 3}

TECHNOCOLONIALISM: DIGITAL AID AS EXTRACTION AND EXPERIMENTALITY

\section{Mirca Madianou \\ Goldsmiths, University of London}

This paper puts forward the notion of technocolonialism to explain the ways digital innovation and data practices revitalise colonial legacies in the humanitarian and international development sectors, which often exemplify so called 'tech-for-good' developments.

The aid sector is increasingly digitized and dependent on metrics and data. Most United Nations agencies have innovation labs and data departments. Refugee registrations by default involve biometric data while needs assessment and the coordination of aid depend on data metrics. Artificial intelligence (Al) applications include chatbots, data visualizations and modelling aiming at forecasting future crises and population flows. Digitization and datafication are transforming the sector and compound the parallel forces of marketization, professionalization and privatization which takes place through the proliferation of private-public partnerships, but also through the work of private entrepreneurs, foundation work and 'big tech' initiatives such as Facebook's 'Disaster Maps' initiative. Such developments encompass both international development and humanitarian initiatives which overlap significantly as aid agencies often engage both in emergency work and long-term recovery (Krause, 2014). Because humanitarianism and development share a similar structure, which follows the flow of aid from the rich Global North to the Global South, I refer to them collectively as the aid sector here.

Technocolonialism refers to the convergence of digital developments with the structures of the aid sector and market forces and the extent to which they reinvigorate and rework colonial relationships of dependency. The paper is divided into three parts: it will first outline why colonialism is an appropriate framework for understanding contemporary developments. In the second part I will illustrate how digital innovation and data practices rework colonial legacies within the aid sector before finally arguing for the wider relevance of this framework which extends beyond the humanitarianism development nexus to the wider technology-for-good sector.

The notion of technocolonialism draws on colonial (Stoler, 2016) and decolonial (Quijano, 2000) theorists who argue for the persistence of colonial genealogies in the contemporary context. Quijano's notion of the 'coloniality of power' is useful for explaining how the subjugation of the colonized continued well after the independence of postcolonial states as a result of the dominance of Eurocentric systems of knowledge, the codification of social and racial discrimination and the exploitation associated with global capitalism (Quijano, 2000). For Stoler, contemporary global inequalities such as migration are 'reworkings [...] of colonial histories' which she theorizes as colonial presence (2016, p. 5).

Humanitarianism and international development are deeply entangled with colonial histories. Humanitarianism emerged in the colonial expansion of the $19^{\text {th }}$ and $20^{\text {th }}$ centuries and the parallel awareness of otherness and suffering (Lester and Dussart, 
2014). Although contemporary humanitarianism is popularly understood in moral terms as the expression of 'a supposed natural humaneness' (Fassin, 2012) and the 'imperative to reduce suffering' (Calhoun, 2000) the structural asymmetry between donors, humanitarian officers and aid recipients reproduces the unequal social orders which shaped colonialism and empire. The emphasis on 'doing good' occludes the fact that aid, including international development, are part of a wider liberal agenda (Escobar, 2012) that primarily benefits countries in the Global North. The asymmetry is evident in the language used in humanitarianism and development to refer to 'aid beneficiaries' and 'donors'. It is in these asymmetrical relationships that we discern the legacies of colonialism.

Technology and science are also part of colonial genealogies. From the development of the $19^{\text {th }}$ century natural sciences to innovations such as the telegraph (Suman, 2009) scientific explorations benefitted from colonial expansion and the parallel resource extraction. Science was integral to the 'civilizing mission' of colonialism, a tool used to justify colonial rule (Fanon, 1959). Science was the prime tool used to mold colonial subjectivities (Anderson, 2006) for example through systems of classification. It is no coincidence that biometrics was first used in India as part of the British Empire's efforts to control and manage colonial subjects. That biometrics is still used today to manage and control othered bodies is evidence of the durability of colonial legacies (Madianou, 2019). Contemporary developments in artificial intelligence (Al) are part of larger genealogies of enumeration, measurement and classification that were originally developed by imperial powers (Appadurai, 1993; see Madianou, 2021 for a discussion of a decolonial approach to $\mathrm{Al}$ ). The colonial genealogies of science are particularly evident in the way colonies were used as laboratories for testing and experimentation (Petryna, 2009). Contemporary experimentation with digital technologies has its roots in those earlier - and more recent - practices of offshoring clinical trials.

Technocolonialism refers to the convergence of digital developments with the genealogies of international aid and the entry of market forces and the extent to which they reinvigorate and rework colonial relationships of dependency. Technocolonialism aims to capture the constitutive role that digital innovation and data play in entrenching existing power asymmetries between people in need and aid agencies. The paper observes that this entrenchment occurs through a number of interconnected processes: by extracting value from 'beneficiary' data and innovation experiments for the benefit of aid organizations and private companies; by materializing discrimination associated with colonial legacies; by contributing to the production of systems of classification and social orders that entrench the 'coloniality of power'; by experimenting with untested technologies; and by justifying these practices under the context of emergencies. The constitutive role of technologies in revitalizing and materialising colonial legacies differentiates technocolonialism from neocolonialism. Technologies here aren't just tools, but the means through which the colonial legacies are reworked and realized in the present moment.

Digital developments in the aid sector are typical of developments in the larger field of 'technology for good', or 'tech-for-good' as it is often referred to. 'Tech-for-good' are initiatives by big technology companies which essentially claim that technologies will provide solutions to complex social problems. Technology, which in this context is 
almost always synonymous with digital technology and computation (see also parallel terms such as 'Al-for-good'), is intentionally designed and developed to address social, economic and environmental challenges. The paper concludes with a reflection on what constitutes 'good' in the face of extraction and experimentality.

\section{References}

Anderson, W. (2006). Colonial Pathologies. Durham and London: Duke University Press.

Appadurai, A. (1993) Number in the Postcolonial Imagination. In Breckenridge, C. \& Van der Veer, P. (Eds.), Orientalism and the Postcolonial Predicament, pp. 314-339. Philadelphia: University of Pennsylvania Press.

Calhoun, C. (2008). The imperative to reduce suffering: charity, progress, and emergencies in the field of humanitarian action. In: Barnett, M. \& Weiss, T. G., (eds.) Humanitarianism in Question: Politics, Power, Ethics. pp. 73-97. Cornell University Press, Ithaca, NY, USA.

Escobar, A. (2012). Encountering Development: The Making and Unmaking of the Third World. Princeton: Princeton University Press.

Fanon, F. (1959). A Dying Colonialism. New York: Grove Press.

Fassin, D. (2012). Humanitarian Reason: A moral history of the present. Berkeley, CA.: University of California Press.

Krause, M. (2014). The Good Project. Chicago, IL: Chicago University Press.

Lester, A., \& Dussart, F. (2014). Colonization and the Origins of Humanitarian Governance. Cambridge: Cambridge University Press.

Madianou, M. (2019a). Technocolonialism: digital innovation and data practices in the humanitarian response to refugee crises. Social Media and Society, 5(3), 1-13. https://doi.org/10.1177/2056305119863146

Madianou, M. (2019b). The Biometric Assemblage: surveillance, experimentation, profit and the measuring of refugee bodies. Television and New Media, vol. 20(6), 581-599. https://doi.org/10.1177/1527476419857682

Madianou, M. (2021). Nonhuman humanitarianism: when 'Al for good' can be harmful. Information, Communication \& Society, 24(6), 850868, DOI: $\underline{10.1080 / 1369118 X .2021 .1909100}$

Petryna, A. (2009). When Experiments Travel. Clinical Trials and the Global Search for Human Subjects. Princeton University Press. 
Quijano, A. (2000). Coloniality of Power and Eurocentrism in Latin America. International Sociology, 15(2), 215-232.

Stoler, A. L. (2016). Duress: Imperial Durabilities in Our Times. Durham and London: Duke University Press.

Suman, S. (2009). Putting knowledge in its place: science, colonialism and the postcolonial. Postcolonial Studies, vol. 12(4), 373-388. 


\section{Paper 4}

\section{THE DECOLONIAL TURN IN DATA STUDIES}

\section{Nick Couldry, London School of Econonics Ulises Meijes, SUNY Oswego}

This talk will return to the proposal, made by the authors at AOIR 2018, to interpret what is going on with data today through the lens of colonialism, specifically through the theoretical framework now known as data colonialism (Couldry and Mejias 2018, 2019).

Data colonialism is just one of a number of macro-theories developed in the past 5 years to make sense of the vast expansion of processes for extracting, aggregating, evaluating and applying data. Most such theories try to capture the contemporary nature of capitalism: for example, surveillance capitalism (Zuboff 2015, 2019), platform capitalism (Srnicek 2016), and data capitalism (Myers West 2017). A minority do so by drawing analogies not only within the history of capitalism, but over a longer time-scale. One example are the theories of digital feudalism represented elsewhere in this panel (Linaa Jensen 2020; Brevini and Swiatek 2020; compare Fairfield 2017). This paper will discuss the distinctive advantages of examining current trends in contemporary capitalism from the perspective of the longer historical time-frame of colonialism: that is, the theory of data colonialism.

The first element of this thesis stems from debates about how, in general, capitalism should be interpreted not as a spontaneously-generating process of $18^{\text {th }}$ century modernity, but as an outgrowth of the extraordinary seizure of global resources by European powers that we know as colonialism, not capitalism. The critique of orthodox Marxism for neglecting the significance to the development of capitalism of what was labelled mere 'primitive accumulation' is well-established (Williams 1994; Robinson 2000). But the point acquires special importance at a time when, through the medium of data, an entirely new dimension of the world's resources is being appropriated as a source of economic value, converting the flow of everyday human life into an input for capitalist production. True, this landgrab (Dorre, Lessenich and Rosa 2015) can be understood as part of capitalism's ongoing expansion, as what David Harvey (2004) called —revising Marx - 'accumulation by dispossession' (c.f. Thatcher, O'Sullivan, and Mahmoudi 2017; Mezzadra and Neilson 2018). But it does more justice both to the epochal nature of colonialism's original landgrab five centuries ago, and to the potentially epochal nature of the contemporary data landgrab, to call the latter development a new stage of colonialism.

This is intended as a strictly limited and strategic comparison. The proposal is not that today's data landgrab is exactly like the original appropriation of land, resources and bodies in all respects, or alike in all of its modalities. Quite clearly it isn't, not least because the new landgrab, unlike its violent predecessor, does not begin in the absence of social relations between the colonizer and the colonized. It begins, instead, against the background of three centuries of developing social relations and marketization of social life within capitalism (Polanyi 2001), making physical violence less necessary. The comparison being made is simply between the scale and depth of the contemporary appropriation of data across everyday life and the transformation of life in colonized territories at the start of historical colonialism. From which it follows also that we are not 
comparing what is happening today, at the beginning of this new landgrab, with what, over centuries, followed the original colonial landgrab (that is, the emergence of complex structures of imperial administration or of cultures of racial oppression and hierarchy).

The structures of power and oppression that will develop from this data landgrab are inevitably still, in part, to be decided. What is clear, however -and this is where the connection between data colonialism and the long and bitter legacy of neocolonial power becomes explicit- is that the power relations of data colonialism will build upon and reinforce the inequalities inherited from earlier eras, not least the inherited racial inequalities of contemporary societies, often understood through the lens of 'racial capitalism' (Bhattacharyya 2018; Cottom 2020). The racial justice inflections of how data colonialism unfolds are already clear (Noble 2018; Benjamin 2019), but they are not the only justice issues raised by data colonialism (there are also class, gender and indigenous rights issues: c.f. Eubanks 2017; Ricaurte 2019; d'Ignazio and Klein 2020; Chock 2020). And the historical resonances of data colonialism extend beyond the implications of racial capitalism to encompass the hierarchical approach both to the production of knowledge and to the ranking of human beings that from the start was used to justify the seizure of the planet's resources (Bhattacharyya 2018: 99; Mignolo 2011; Pagden 1986; Schmitt 2006).

This is the second main element of the data colonialism thesis: that only within this extended historical frame can the continuity of extractivism be grasped, a continuity that is invisible within accounts that see data practices only within the history of capitalism or only within the history of Europe. This continuity is the idea that Peruvian postcolonial theorist Aníbal Quijano (2007/1992) called 'coloniality'. In essence, it is what justifies power and the absolute seizure of the world's assets on the basis of an assumed 'rational' superiority located somehow in 'the West', or in whatever parts of the world now assume the mantle of 'the West'. The data colonialism approach links well-known critiques of the discourse of dataism (Van Dijck 2014) to a deeper continuity in how the seizure of the world's resources has been justified throughout the history of colonialism and its offshoot, capitalism. This changes our understanding of contemporary discourses of Big Data, whether within rich societies (where the full force of their dispossessive power becomes clear) or between richer and poorer societies (where they play out, as already noted, against the backdrop of neocolonial inequalities).

From this perspective, the data colonialism thesis will be presented along two dimensions. First, as a way to appreciate the full scale of the annexation of human life to capital through the medium of data. And second, as a way to understand the historic continuities of rationality that 'justify' this new landgrab, as they did earlier colonial appropriations.

Our proposal, in short, is that data represents a social transformation that can only be understood by grasping the evolving order of contemporary data-driven capitalism through the historical comparative lens of colonialism, which itself was the starting-point for capitalism. In that sense, similarities between this new order and earlier social orders such as feudalism that predate both colonialism and capitalism are accidental, rather than explanatory. Data colonialism, along with historical colonialism and capitalism, must all be understood as phases in the development of 'modernity' as strategies for world domination, not merely localized feudal oppression. 


\section{References}

Benjamin, R. (2019). Race After Technology. Polity.

Bhattacharyya, G. (2018). Rethinking Racial Capitalism. Rowman and Littlefield.

Brevini, B. and Swiatek, L. (2020) Amazon. London: Routledge.

Chock, S. Costanza (2020). Design Justice. MIT Press.

Cottom, T. (2020). Where Platform Capitalism and Racial Capitalism Meet: The Sociology of Race and Racism in Digital Society. Sociology of Race and Ethnicity, 6(4), 441-449.

Couldry, N. and Mejias, U. (2018) 'Data Colonialism: Rethinking Big Data's Relation to the contemporary subject', Television \& New Media.

https://doi.org/10.1177\%2F1527476418796632

Couldry, N. and Mejias, U. (2019) The Costs of Connection. Stanford: Stanford University Press.

Eubanks, V. (2018). Automating Inequality. St. Martin's Press.

Fairfield, J. (2017) Owned. Cambridge: Cambridge University Press.

Harvey, D. (2004). The 'New' Imperialism: Accumulation by Dispossession. Socialist Register, 40, 63-87.

Linaa Jensen, J. (2020) The Medieval Internet. Emerald Publishing.

Mezzadra, S. \& Neilson, B. (2018). The Politics of Operation. Duke University Press.

Mignolo, W. (2011). The Darker Side of Modernity. Duke University Press.

Myers West, S. (2017) 'Data Capitalism: Redefining the Logics of Surveillance ad Privacy' Business and Society https://doi.org/10.1177\%2F0007650317718185

Noble, S. (2018). Algorithms of Oppression. NYU Press.

Pagden, A. (1987). The Fall of Natural Man (2nd ed). Cambridge University Press.

Polanyi, K. (2001) The Great Transformation. Boston: Beacon Press.

Quijano, A. (2007). 'Coloniality and Modernity/Rationality', Cultural Studies 21(2): 168178.

Ricaurte, P. (2019). Data Epistemologies, The Coloniality of Power, and Resistance. 
Television \& New Media, 20(4), 350-365.

Robinson, C. (2000). Black Marxism (2nd ed.). University of North Carolina Press.

Schmitt, C. (2006). The Nomos of the Earth. Telos Press Publishing.

Srnicek, N. (2017). Platform Capitalism. Polity.

Thatcher, J., O'Sullivan, D., \& Mahmoudi, D. (2017). Data Colonialism Through Accumulation by Dispossession: New Metaphors for Daily Data. Environment andPlanning D: Society and Space, 34(6): 990-1006.

van Dijck, J. (2014) 'Datafication, Dataism and Dataveillance', Surveillance and Society, 12(2), pp. 197-208.

Williams, E. (1994). Capitalism and Slavery. University of North Carolina Press.

Zuboff, S. (2019). The Age of Surveillance Capitalism. Profile Books. 